\title{
Comparison of GOME-2/MetOp total ozone data with Brewer spectroradiometer data over the Iberian Peninsula
}

\author{
M. Antón ${ }^{1}$, D. Loyola ${ }^{2}$, M. López ${ }^{3}$, J. M. Vilaplana ${ }^{4}$, M. Bañón ${ }^{3}$, W. Zimmer ${ }^{2}$, and A. Serrano ${ }^{1}$ \\ ${ }^{1}$ Departamento de Física, Universidad de Extremadura, Badajoz, Spain \\ ${ }^{2}$ Remote Sensing Technology Institute (IMF), German Aerospace Center (DLR), Wessling, Germany \\ ${ }^{3}$ Agencia Estatal de Meteorología (AEMet), Madrid, Spain \\ ${ }^{4}$ Estación de Sondeos Atmosférico "El Arenosillo", Instituto Nacional de Técnica Aeroespacial (INTA), Huelva, Spain \\ Received: 21 November 2008 - Revised: 9 February 2009 - Accepted: 19 February 2009 - Published: 1 April 2009
}

\begin{abstract}
The main objective of this article is to compare the total ozone data from the new Global Ozone Monitoring Experiment instrument (GOME-2/MetOp) with reliable ground-based measurement recorded by five Brewer spectroradiometers in the Iberian Peninsula. In addition, a similar comparison for the predecessor instrument GOME/ERS2 is described. The period of study is a whole year from May 2007 to April 2008. The results show that GOME2/MetOp ozone data already has a very good quality, total ozone columns are on average 3.05\% lower than Brewer measurements. This underestimation is higher than that obtained for GOME/ERS-2 (1.46\%). However, the relative differences between GOME-2/MetOp and Brewer measurements show significantly lower variability than the differences between GOME/ERS-2 and Brewer data. Dependencies of these relative differences with respect to the satellite solar zenith angle (SZA), the satellite scan angle, the satellite cloud cover fraction (CF), and the ground-based total ozone measurements are analyzed. For both GOME instruments, differences show no significant dependence on SZA. However, GOME-2/MetOp data show a significant dependence on the satellite scan angle $(+1.5 \%)$. In addition, GOME/ERS-2 differences present a clear dependence with respect to the $\mathrm{CF}$ and ground-based total ozone; such differences are minimized for GOME-2/MetOp. The comparison between the daily total ozone values provided by both GOME instruments shows that GOME-2/MetOp ozone data are on average $1.46 \%$ lower than GOME/ERS-2 data without any seasonal dependence. Finally, deviations of a priori climatological ozone profile used by the satellite retrieval algorithm from the true ozone profile are analyzed. Although ex-
\end{abstract}

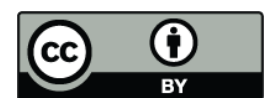

Correspondence to: M. Antón (mananton@unex.es) cellent agreement between a priori climatological and measured partial ozone values is found for the middle and high stratosphere, relative differences greater than $15 \%$ are common for the troposphere and lower stratosphere.

Keywords. Atmospheric composition and structure (Middle atmosphere - composition and chemistry; Instruments and techniques)

\section{Introduction}

Ozone depletion is a well known atmospheric phenomenon, and in recent years there has been strong interest in the expected future ozone recovery (WMO, 2006). It is of great importance to obtain a global long-term accurate record of ozone measurements. Satellite data complement groundbased measurements, providing global daily maps with uniform spatial coverage using a single instrument. To ensure the quality of remote sensing observations, the intercomparison of satellite products with reliable ground-based measurements is a crucial activity (WMO, 1999). In addition, ozone data obtained by satellite instruments have been used to estimate the performance of the ground-based network, since notable changes for individual stations in the ground-satellite differences are usually related to problems in ground-based records (Fioletov et al., 2008).

MetOp-A (Meteorological Operational satellite program) is the first in a series of three similar meteorological satellites from EUMESAT. MetOp-A was launched in October 2006. One of the instruments on board this satellite is the Global Ozone Monitoring Experiment 2 (GOME-2) (Munro et al., 2006). This instrument is operating concurrently with its two European predecessors: the GOME instrument onboard ESA's Second European Sensing Satellite (ERS-2) launched

Published by Copernicus Publications on behalf of the European Geosciences Union. 
in April 1995 (Burrows et al., 1999a), and the SCIAMACHY sensor onboard ENVISAT launched in March 2002 (Bovensmann et al., 1999). This total ozone time series will continue to at least 2020 with the GOME-2 sensors onboard the MetOp satellites; two other MetOp satellites will be launched in 2011 and 2015.

During the last decade, GOME/ERS-2 total ozone data have been compared extensively with ground measurements using mostly Dobson and Brewer spectroradiometers (Hansen et al., 1999; Lambert et al., 1999, 2002; Bramstedt et al., 2003; Vanicek, 2006). These validation exercises identified several discrepancies in the initial versions of GOME/ERS-2 total ozone data compared with groundbased measurements. These discrepancies have largely been resolved, and with the most recent global-scale validation work of Balis et al. (2007a), the average agreement of GOME/ERS-2 total ozone column with ground-based and other satellite ozone observations is at the one percent level. A comprehensive validation of GOME/ERS-2 total ozone data over the Iberian Peninsula for the period 1995-2005 can be found in the work of Antón et al. (2008). This work showed an excellent agreement between the current operational GOME/ERS-2 total ozone data and ground-based measurements from five Brewer instruments.

The first GOME-2 total ozone data has been available since March 2007. To our knowledge, only two validation exercises for GOME-2 total ozone have been published to date as part of EUMETSAT's Satellite Application Facility on Ozone and Atmospheric Chemistry Monitoring (O3MSAF) (Balis et al., 2007b, 2008). Therefore, it is important to perform a continuous validation of the operational GOME2/MetOp total ozone using reliable ground-based data. The main objective of this paper is to compare total ozone data provided by GOME-2/MetOp satellite instrument with spatially and temporally co-located ground-based measurements from well-calibrated Spanish Brewer spectroradiometers for a whole year of data (between May 2007 and April 2008). The main advantage of using a dense local ground-based network is that all instruments follow the same protocol of calibration. In this regard, the Spanish Brewer spectroradiometers possess an excellent maintenance record. These instruments are periodically intercompared and calibrated with respect to the international reference instrument (Labajo et al., 2004). In contrast, global-scale ozone intercomparisons between satellite and ground-based instruments are performed using Dobson or Brewer instruments with different calibration procedures and not intercompared. This fact could produce unknown station-to-station biases.

GOME/ERS-2 total ozone data recorded during the same period were also compared with Brewer spectroradiometer data in order to check the consistency of the total ozone data provide by the two GOME instruments.

This article is structured as follows: Sect. 2 describes the satellite and ground-based measurements data sets, and summarizes the validation methodology. Section 3 compares co- located GOME-2/MetOp and GOME/ERS-2 total ozone data with those from the Iberian Peninsula Brewer network. In addition, this section also discusses differences between measured ozone profiles and those used as a priori climatology in the satellite ozone retrievals. Finally, Sect. 4 summarizes the main conclusions.

\section{Data and methodology}

\subsection{Satellite data}

GOME-2/MetOp is an enhanced version of GOME/ERS2 , covering the same spectral range from about 240 to $790 \mathrm{~nm}$. Compared to the GOME/ERS-2 instrument, GOME-2/MetOp has a four times higher spatial resolution of $80 \mathrm{~km} \times 40 \mathrm{~km}$. Also, GOME-2/MetOp has an improved temporal coverage with respect to GOME/ERS-2. GOME2/MetOp has a larger swath width of $1920 \mathrm{~km}$ (twice that of GOME/ERS-2), resulting in a daily near global coverage at the equator (global coverage is achieved with GOME/ERS2 within three days). The MetOp orbit is sun-synchronous, with an equator crossing time of 09:30 LT (compared to 10:30 LT for ERS-2). Thus, both GOME instruments can observe almost the same scene within about one hour.

The operational algorithm for the retrieval of total ozone column from the GOME-2/MetOp is the GOME-2 Data Processor Version 4.2 (GDP 4.2), which is based on the operational GDP 4.0 algorithm used with GOME/ERS-2. The GDP algorithm has undergone several years of progressive improvement since its first release in 1995 (Loyola et al., 1997; Burrows et al., 1999b; Spurr et al., 2005; Van Roozendael et al., 2006). In GDP the ozone slant columns are derived with a standard Differential Optical Absorption Spectroscopy (DOAS) retrieval. Ozone vertical columns are then obtained dividing the slant column by appropriated Air Mass Factors (AMF) computed with an iterative on-fly radiative transfer model simulations. The major improvements in GDP 4.0 (Van Roozendael et al., 2006) compared with GDP 3.0 (Spurr et al., 2005) are the Ring correction, and new algorithms for delivering cloud information from GOME measurements. GDP 4.2 includes new features needed for GOME-2 such as the discrimination between clouds and Sun-glint, and a correction for intra-cloud ozone. A detailed description of current GDP 4.2 can be found in the work of Valks and Loyola (2008).

\subsection{Ground-based measurements}

The ground-based total ozone data have been measured by five Brewer spectroradiometers located in the Iberian Peninsula. These instruments belong to the Spanish Brewer spectrophotometers network which is maintained by the Spanish Agency of Meteorology (AEMet). The ground-based stations used in this study are from north to south: Coruña $\left(43.33^{\circ} \mathrm{N}, 8.42^{\circ} \mathrm{W}\right)$, Zaragoza $\left(41.01^{\circ} \mathrm{N}, 1.01^{\circ} \mathrm{W}\right)$, Madrid 
Table 1. Parameters obtained in the correlation analysis between GOME-2/MetOp ozone data and ground-based measurements. Results for the GOME/ERS-2 correlation are shown in parentheses.

\begin{tabular}{lcccccc}
\hline & $N$ & Slope & $R^{2}$ & RMSE (\%) & MBE (\%) & MABE (\%) \\
\hline Madrid & 294 & $0.99 \pm 0.01$ & 0.96 & 2.07 & $-2.92 \pm 0.12$ & $3.09 \pm 0.10$ \\
& $(123)$ & $(1.01 \pm 0.03)$ & $(0.92)$ & $(2.86)$ & $(-1.70 \pm 0.24)$ & $(2.50 \pm 0.18)$ \\
Murcia & 286 & $0.97 \pm 0.01$ & 0.96 & 1.84 & $-3.65 \pm 0.11$ & $3.71 \pm 0.10$ \\
& $(134)$ & $(0.99 \pm 0.02)$ & $(0.95)$ & $(2.17)$ & $(-1.18 \pm 0.18)$ & $(1.96 \pm 0.12)$ \\
Coruña & 270 & $1.00 \pm 0.01$ & 0.95 & 2.40 & $-3.45 \pm 0.14$ & $3.71 \pm 0.12$ \\
& $(113)$ & $(0.98 \pm 0.02)$ & $(0.93)$ & $(2.80)$ & $(-1.97 \pm 0.26)$ & $(2.74 \pm 0.19)$ \\
Zaragoza & 282 & $0.97 \pm 0.01$ & 0.95 & 2.19 & $-2.74 \pm 0.13$ & $3.02 \pm 0.10$ \\
& $(134)$ & $(1.02 \pm 0.02)$ & $(0.95)$ & $(2.32)$ & $(-1.82 \pm 0.20)$ & $(2.41 \pm 0.14)$ \\
Arenosillo & 309 & $0.98 \pm 0.01$ & 0.93 & 2.14 & $-2.67 \pm 0.12$ & $2.93 \pm 0.09$ \\
& $(123)$ & $(0.99 \pm 0.02)$ & $(0.93)$ & $(2.29)$ & $(-1.00 \pm 0.20)$ & $(1.96 \pm 0.13)$ \\
Iberian Peninsula & 1441 & $0.99 \pm 0.01$ & 0.95 & 2.16 & $-3.07 \pm 0.06$ & $3.28 \pm 0.05$ \\
& $(627)$ & $(1.00 \pm 0.01)$ & $(0.93)$ & $(2.51)$ & $(-1.53 \pm 0.10)$ & $(2.31 \pm 0.07)$ \\
\hline
\end{tabular}

$\left(40.45^{\circ} \mathrm{N}, 3.72^{\circ} \mathrm{W}\right)$, Murcia $\left(38.03^{\circ} \mathrm{N}, 1.17^{\circ} \mathrm{W}\right)$ and $\mathrm{El}$ Arenosillo $\left(37.06^{\circ} \mathrm{N}, 6.44^{\circ} \mathrm{W}\right)$. The Brewer instruments located in these stations were installed between 1992 and 2000, and they are biannually calibrated by intercomparison with the travelling reference Brewer \#017 from the International Ozone Services (IOS). In this way the ozone calibration is traceable to the triad of reference Brewer spectrophotometers maintained by MSC (Meteorological Service of Canada) at Toronto (Fioletov et al., 2005). The five inter-comparisons carried out at the El Arenosillo station with the reference travelling Brewer instrument confirm the reliability of the Spanish Brewer calibration (Redondas et al., 2002; Labajo et al., 2004).

In the present validation, only the most accurate Brewer ozone data obtained through direct sunlight (DS) measurements were used. When Brewer spectrophotometers are properly calibrated and regularly maintained, the total ozone column records obtained through DS measurements can potentially maintain a precision of $1 \%$ over long time intervals (WMO, 1996). A detailed description, of the methodology used by the Brewer spectrophotometers to measure the total ozone amount from direct sunlight, can be found in the works of Kerr et al. (1984) and Kerr et al. (2002).

Ozonesonde profiles, obtained between May 2007 and April 2008 at Madrid, have also been included in this work. The ozone profile measurements were made by balloonborne ozonesondes employing an Electrochemical Concentration Cell (ECC) sensor (Komhyr, 1969). In this cell, the electrical current is directly related to the uptake rate of ozone in the cathode chamber. The subtype of ECC ozonesondes used at Madrid is 6a sonde manufactured by Science Pump Corporation, Camden, New Jersey. The ozonesondes have been interfaced to Vaisala RS80-15G radiosondes. The balloons ascended, on average, to altitudes of $30-35 \mathrm{~km}$.

\subsection{Comparison procedure}

The ground-based measurements used in this paper are daily averages, not single measurements at the time of the satellite overpass. Thus, the same daily Brewer measurement is compared with the satellite observations of both GOME instruments.

Each day, the single GOME/ERS-2 and GOME-2/MetOp ground pixels, most clearly collocated with the location of the Brewer stations, are selected as the best match. The maximum distance allowed between the centre of the satellite pixel and the ground-based location is $200 \mathrm{~km}$.

Time series of both satellite and ground based total ozone data extend from May 2007 to April 2008 (a full year of satellite measurements). Table 1 shows the number of pairs $(\mathrm{N})$ of Brewer- GOME/ERS-2 and Brewer- GOME-2/MetOp data sorted by location.

McPeters et al. (2008) showed that the use of a network in validation studies provides more reliable results than stationby-station analyses. Thus, in addition to individual station comparisons, we present GOME-Brewer comparisons for the Spanish network as a whole. This latter data set is termed "Iberian Peninsula" in the sequel.

The relative differences (RD) between the daily Brewer measurements and satellite observations were calculated for each day and each location by the following expression:

$\mathrm{RD}_{i}=100 \frac{\mathrm{GOME}_{i}-\text { Brewer }_{i}}{\text { Brewer }_{i}}$

From these relative differences the mean absolute bias error (MABE) and the mean bias error (MBE) parameters were also calculated for each location and "Iberian Peninsula" dataset:

$\mathrm{MABE}=\frac{1}{N} \sum_{i=1}^{N}\left|\mathrm{RD}_{i}\right|$ 


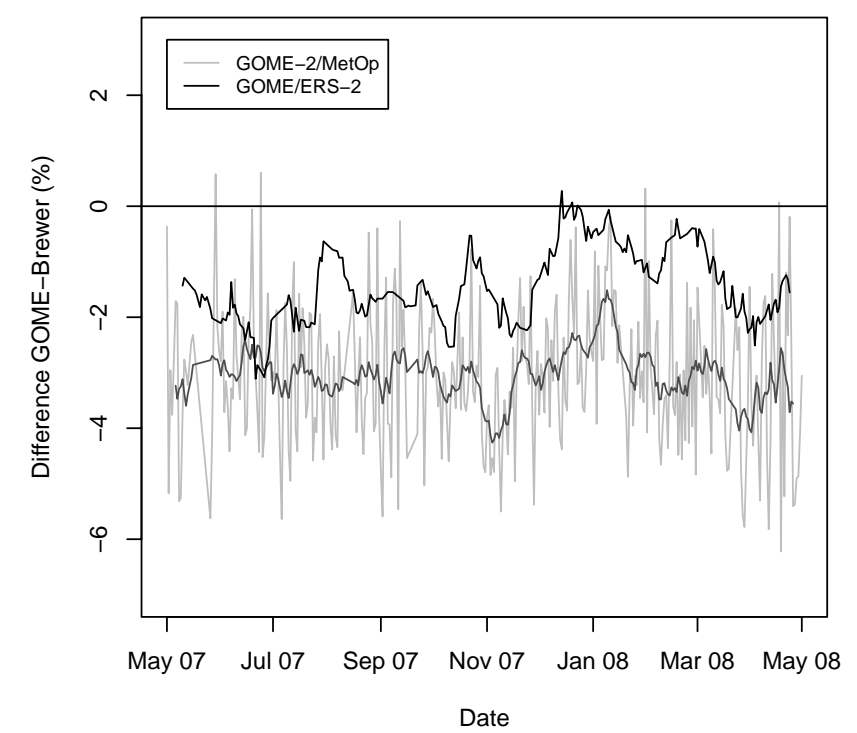

Fig. 1. Seasonal variation of the daily relative differences between Brewer daily total ozone values and GOME-2/MetOp data (grey line), and running mean over ten days (dark grey line) for the "Iberian Peninsula" dataset. The black line denotes the running mean over ten days for the relative differences obtained with GOME/ERS-2 data.

$\mathrm{MBE}=\frac{1}{N} \sum_{i=1}^{N} \mathrm{RD}_{i}$

where $N$ is the number of data pairs (see Table 1).

In addition, a regression analysis is performed for each location and the "Iberian Peninsula" dataset. Regression coefficients, coefficients of correlation $\left(R^{2}\right)$ and the root mean square errors (RMSE) were evaluated in this analysis.

\section{Results and discussion}

\subsection{Total ozone comparisons}

The temporal evolution of the daily relative differences between GOME-2/MetOp ozone data and Brewer measurements at the Iberian Peninsula is shown in Fig. 1. Each point on the plot (in grey colour) represents the mean value of all relative differences for each day (a maximum of five values per day). The number of the days is 336 . The running average over ten days is superimposed on the daily results. It is seen that GOME-2/MetOp agreed remarkably well with the ground network. The daily differences between Brewer measurements and GOME-2/MetOp ozone data are mostly within $5 \%$, and about half of the differences are within $3 \%$. However, from this figure, it can be seen that GOME2/MetOp observations underestimate the Brewer measurements over the period of comparison. The relative difference average is $-3.05 \%$ with $\pm 1.28 \%$ one standard deviation (s.d.). This result is consistent with corresponding results

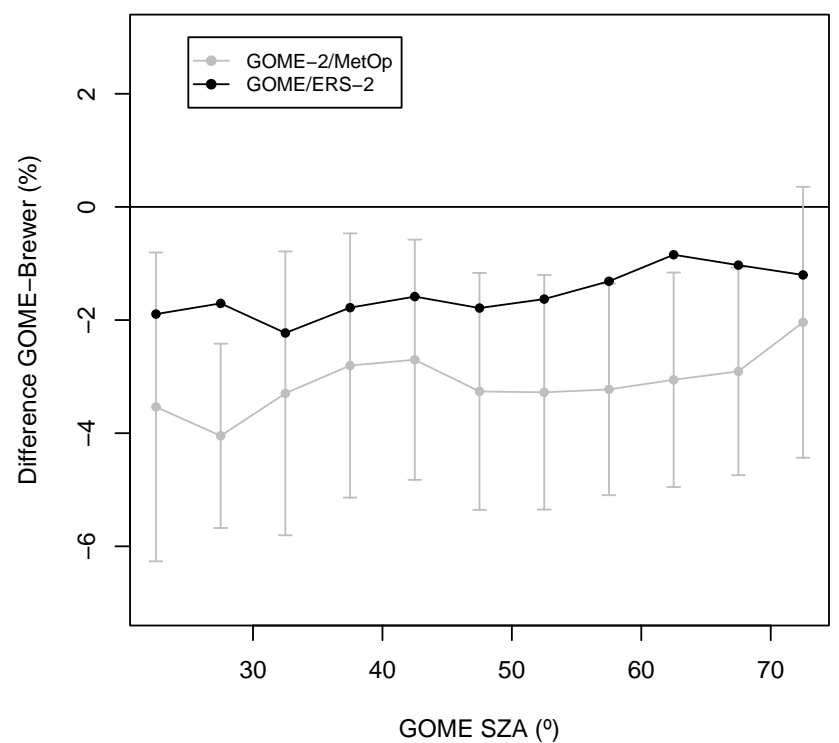

Fig. 2. Dependence of GOME-Brewer relative differences with respect to the GOME solar zenith angle (SZA) for the "Iberian Peninsula" dataset.

of the comparison work of Balis et al. (2008) for individual stations at the Iberian Peninsula (El Arenosillo, Madrid and Murcia).

The time series of the relative Brewer-GOME/ERS-2 differences (239 in all) is also shown in Fig. 1, as the 10-day running average (black line). The negative bias is smaller, with an average value of $-1.46 \%( \pm 1.93 \%$ one s.d.). The larger magnitude of the GOME-2/MetOp bias is attributed in part to the Level $1 \mathrm{~b}$ radiometric calibration and retrieval issues in the level 2 processing (Balis et al., 2007b, 2008). In addition, the temporal evolution of the differences for both satellite instruments does not show any seasonal dependency. Therefore, there is no evidence for significant change in the GOME observations over the period of comparison.

The next step in the comparison is to perform linear regression analyses on the Brewer-GOME differences. Gradients and statistics are given in Table 1. Correlation between both GOME data sets and Brewer measurements are high for all stations and the "Iberian Peninsula" dataset $\left(R^{2}\right.$ higher than 0.92). The negative sign of the MBE parameters show that both GOME instruments underestimate the Brewer data at all locations. In addition, when MBE values are compared for individual stations, it is seen that MBE values for GOME/ERS-2 are smaller that those for GOME-2/MetOp. On the other hand, it can be observed that the RMSE values obtained with GOME-2/MetOp are lower that the values obtained with GOME/ERS-2. In addition, the parameter uncertainty (standard error) is lower for the Brewer-GOME2/MetOp comparison. The reduced RMSE and uncertainty from GOME-2/MetOp total ozone are probably due to the higher signal to noise response of the instrument and to the 


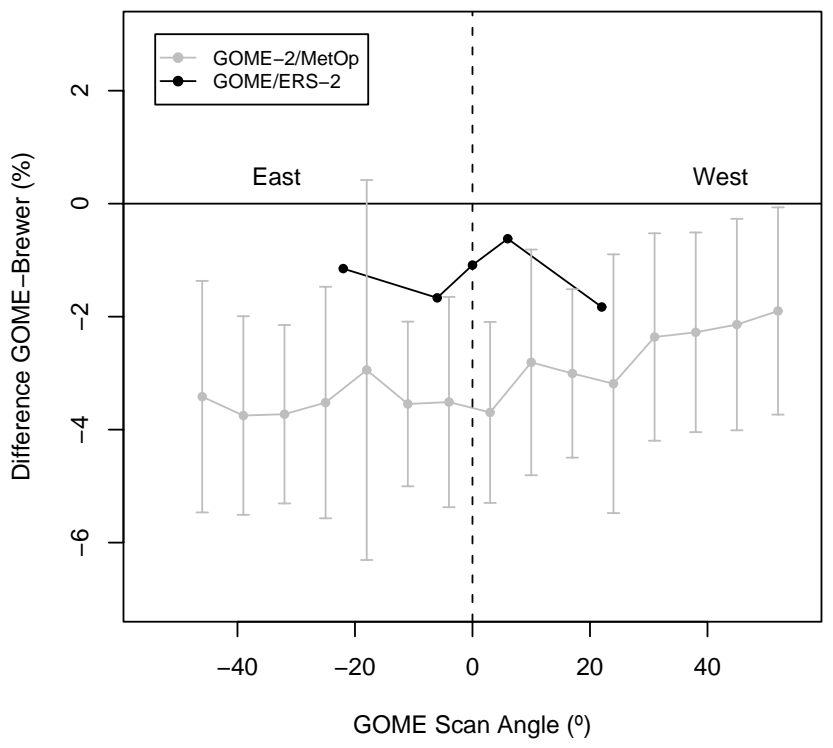

Fig. 3. Dependence of GOME-Brewer relative differences with respect to the GOME scan angle for the "Iberian Peninsula" dataset.

smaller ground pixel size (Munro et al., 2006). Although absolute Brewer-GOME-2/MetOp differences are larger than those for Brewer-GOME/ERS-2, the dispersion is lower. Finally, the MABE is less than $3.71 \%$ for GOME-2/MetOp and $2.74 \%$ for GOME/ERS-2 in all locations. The uncertainty in this parameter is less than $0.12 \%$ (for GOME-2/MetOp) and $0.19 \%$ (for GOME/ERS-2), indicating the statistical significance of the reported values.

The GOME-2/MetOp ozone values have also been compared to the Spanish network of Brewer stations as a function of satellite solar zenith angle (SZA), satellite scan angle, satellite cloud cover fraction (CF), and Brewer total ozone measurements. The dependence of GOME-2/MetOp against these variables is contrasted with the behaviour of GOME/ERS-2 in the following figures.

Using 5-degree divisions of SZA, Fig. 2 shows the mean relative differences between ground based and GOME2/MetOp as a function of satellite SZA (in grey), along with the satellite SZA dependence of GOME/ERS-2 (in black) for comparison. Error bars represent the standard deviations which are plotted for GOME-2/MetOp but, in the interest of clarity, not for GOME/ERS-2. The differences between both satellite instruments and ground-based data show practically no dependence on the GOME SZA in the Iberian Peninsula. Antón et al. (2008) showed that this lack of SZA dependence could be attributed to compensating effects in mixed cloudiness scenarios. Therefore, the relative differences between GOME-2/MetOp and Brewer data were calculated for two opposite cases: cloud-free conditions $(\mathrm{CF}=0 \%)$ and largely cloudy conditions $(\mathrm{CF}>70 \%)$. When the relative differences are represented as a function of the SZA (not shown), the two curves follow a similar pattern. Therefore, GOME-2/MetOp

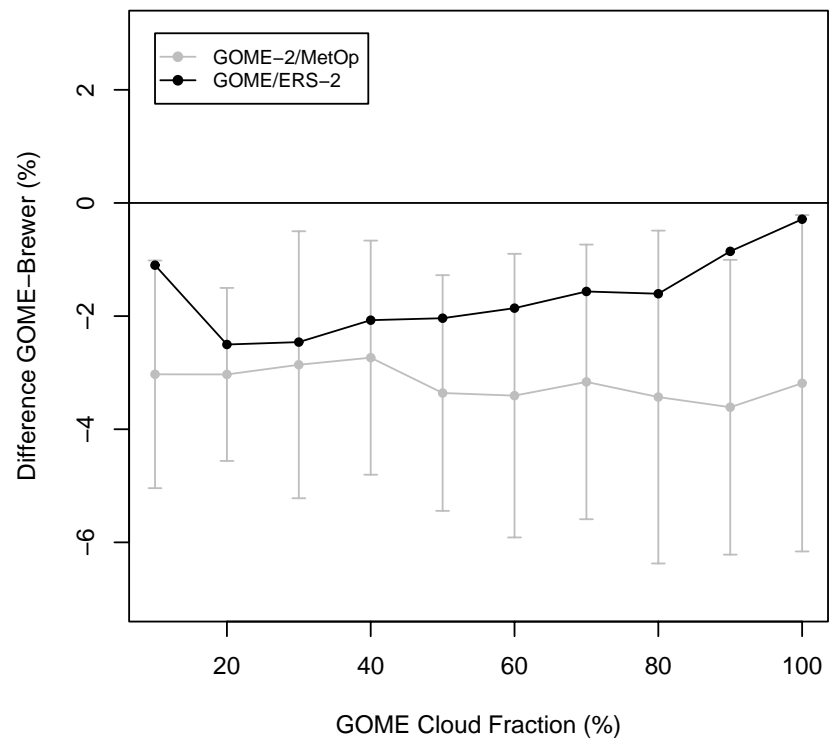

Fig. 4. Dependence of GOME-Brewer relative differences with respect to the GOME cloud cover fraction $(\mathrm{CF})$ for the "Iberian Peninsula" dataset.

instrument show no dependence on the SZA for different sky conditions.

Balis et al. (2008) showed that the GOME-2/MetOp total ozone data possesses a significant dependence with the satellite scan angle. In Fig. 3, the relative differences between GOME and Brewer total ozone data in the Iberian Peninsula are plotted as a function of the scan angle. The lower number of points for GOME-1/ERS-2 arises from the relative dearth of subpixels for this instrument. For GOME-2/MetOp, there is a notable bias (about $+1.5 \%$ ) between the relative differences for the west and east pixels (west higher than east). In contrast, no significant scan angle dependency is seen for GOME/ERS-2 differences. Some possible causes for GOME-2/MetOp scan angle dependency could be the use of a scalar radiation transfer for the calculation of the AMF, and remaining calibration issues in the GOME-2/MetOp level-1 spectra. The origin of this scan angle dependency is currently under investigation.

The relative differences between ground-based measurements and satellite data as a function of GOME cloud fraction, are shown in Fig. 4. While the cloud dependent error of GOME/ERS-2 shows a smooth, positive dependence with the $\mathrm{CF}$ values (for higher $\mathrm{CF}$ values the differences are close to zero), GOME-2/MetOp has no apparent satellite CF dependence. This figure shows the remarkable stability of the GOME-2/MetOp instrument even when the satellite cloud fraction is large. This improvement arises in part from the use of smaller GOME-2 footprints, and also as a result of recent upgrades to cloud retrieval and correction algorithms used in GOME-2/MetOp (Loyola et al., 2007). 


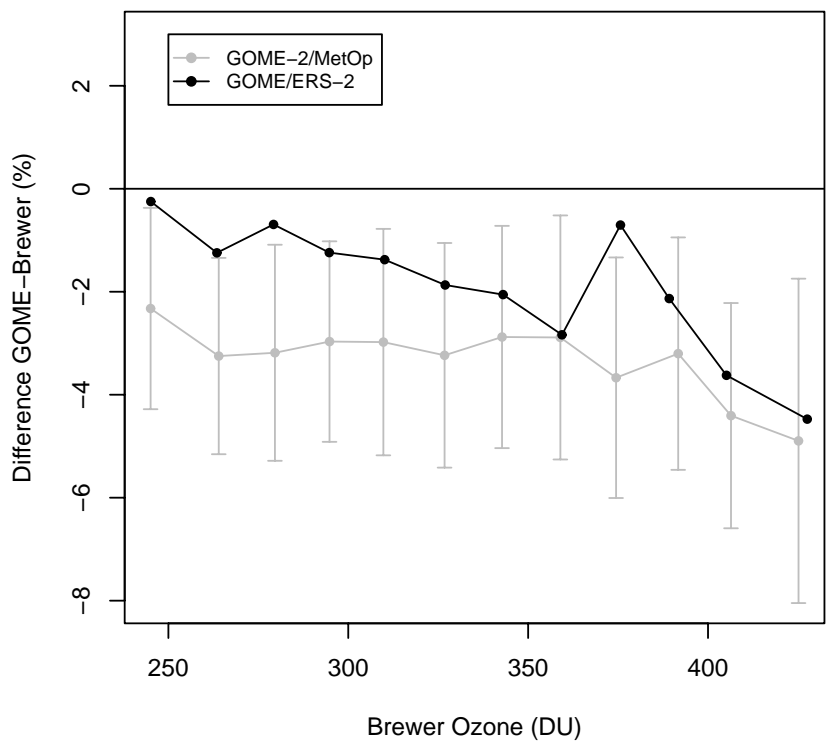

Fig. 5. Variation of GOME-Brewer relative differences with Brewer ozone measurements for the "Iberian Peninsula" dataset.

It has been shown by a number of groups that total ozone observations from GOME/ERS-2 do not completely cover the ozone variability recorded by the ground-based instruments (Lambert et al., 2002; Balis et al., 2007a; Antón et al., 2008). Figure 5 shows the relative differences between ground-based and satellite data as a function of the Brewer total ozone column for GOME/ERS-2 and GOME2/MetOp instruments. Clearly, GOME/ERS-2 has a negative bias with respect to the Brewer data. Thus, the relative differences are close to zero for low total ozone values (230250 Dobson Units [DU]), and the total ozone dependent error of GOME/ERS-2 increases to almost $-5 \%$ by high total ozone values (420-450 DU). In contrast, GOME-2/MetOp has a much smoother total ozone dependence, with the relative differences about $-3 \%$ except at the highest total ozone values where the deviation increases to $-5 \%$. This fact could be related to the differences between the true and the a priori climatological ozone profiles used in GDP (discussed in Sect. 3.2).

The intercomparison between both GOME satellite instruments is analyzed for the period of study and for the "Iberian Peninsula" dataset. The number of simultaneous daily cases is 566. Figure 6 (top) shows the scatter plot between both GOME ozone data. The dashed line is zero bias line (unit slope) and the solid line is the regression line, showing negative GOME-2/MetOp bias. The agreement is high with a coefficient of correlation of 0.92 . In addition, the noise is significantly low (RMSE $=1.47 \%$ ). For about $75 \%$ of all cases, GOME-2/MetOp underestimates GOME/ERS2 , with an average relative difference (GOME-2/MetOp minus GOME/ERS-2 divided by GOME/ERS-2) of $-1.46 \%$ $( \pm 2.72 \%$ one s.d.). A value of the standard deviation lower
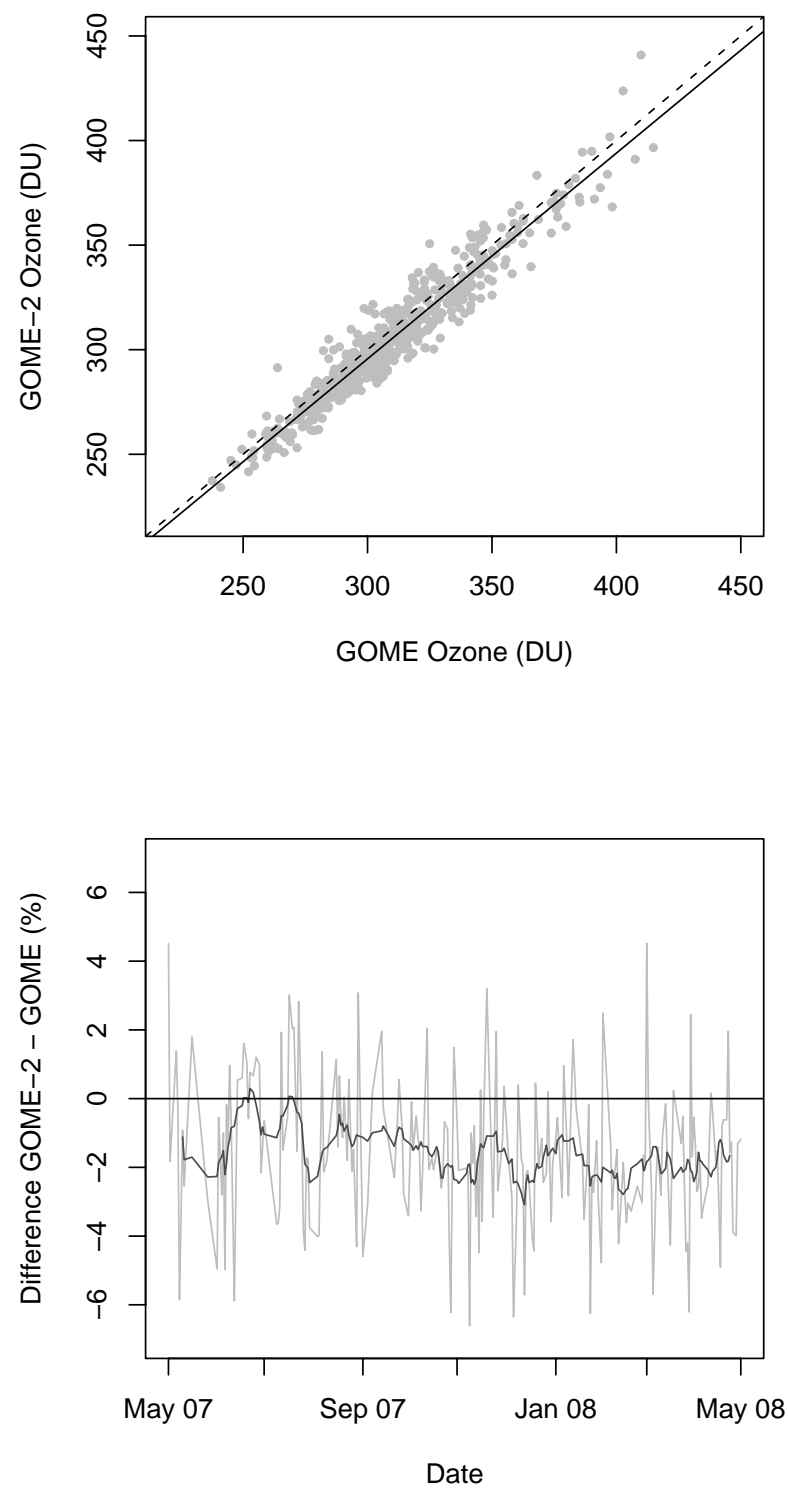

Fig. 6. Correlation between GOME/ERS-2 and GOME-2/MetOp total ozone data for the "Iberian Peninsula" dataset (top panel); the regression line (solid line) and unit slope (dashed line) show the good agreement. Seasonal variation (low panel) of the daily relative difference between GOME/ERS-2 and GOME-2/MetOp total ozone data (grey line), and the corresponding running mean over ten days (dark grey line).

than $3 \%$ suggests that random errors of satellite instruments and the total ozone variability due to a difference in observation time between both satellites are relatively small. The lower panel of Fig. 6 shows the time series of the relative differences; there are no apparent seasonal dependencies.

The above results should be only considered representative for the area of study. All results are based on one full year of data from five ground-based instruments located in the Iberian Peninsula, and thus these numbers could change when more instruments located in other areas are included. 

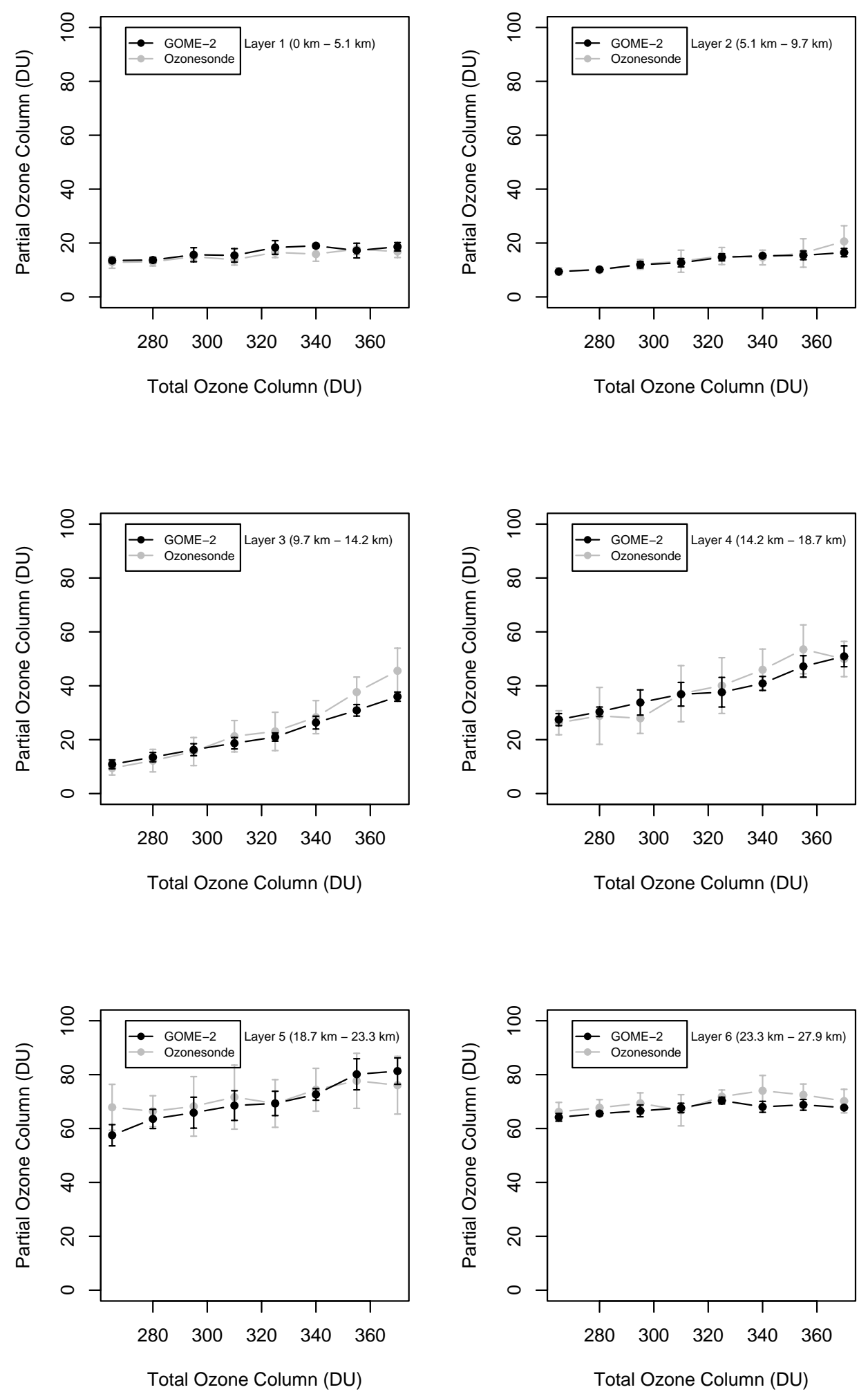

Fig. 7. Partial ozone amounts for 6 layers of the TOMS V8 climatology as a function of ground-based total ozone at Madrid. The grey points represent the mean values of ozonesonde measurements for each Brewer ozone interval, and the black points represent the corresponding mean ozone amount from the TOMS V8 climatology used as a priori in the GOME-2/MetOp ozone retrieval. In both cases, the error bars represent one standard deviation. 


\subsection{Ozone profile comparisons}

It is known that the a priori climatological ozone profiles play an important role in the accuracy of total ozone retrieval by satellite instruments (Lamsal et al., 2007). In GDP 4.0 and GDP 4.2 (hereafter denoted as GDP 4.x), the ghost column (the ozone amount below the cloud top height) and the AMF computation are based on the TOMS version 8 ozone profile climatology (Roozendael et al., 2006). The TOMS V8 profiles are classified as a function of latitude, time, and total ozone, thus GDP 4.x uses an iterative algorithm to ensure the consistency between the integrated a priori ozone and the retrieved total ozone. In order to check that the climatology used in the retrieval correctly reproduces the actual ozone profiles, 48 ozonesonde measurements taken at Madrid between May 2007 and April 2008 were compared with a priori ozone profiles used in the GOME-2/MetOp total ozone retrieval algorithm. Individual ozonesonde readings in units of partial pressure were converted to DUs in order to obtain partial columns corresponding to the layering scheme found in the TOMS V8 climotology.

Figure 7 shows a priori TOMS V8 partial columns as a function of total ozone measured at Madrid. Corresponding ozonesonde data are also shown in Fig. 7. Points indicate mean values of partial column amounts obtained by averaging in $15 \mathrm{DU}$ total ozone bins. Error bars represent the standard deviation of partial ozone values corresponding to each interval. Climatological partial ozone columns show very good agreement with respect to the ozonesonde values for layer \#4 (between $14.2 \mathrm{~km}$ and $18.7 \mathrm{~km}$ ), layer \#5 (between $18.7 \mathrm{~km}$ and $23.3 \mathrm{~km}$ ) and layer \#6 (between $23.3 \mathrm{~km}$ and $27.9 \mathrm{~km}$ ). In contrast, the relative differences between the measured and climatological data are greater for the three lowest layers (below $14.2 \mathrm{~km}$ ). The absolute mean relative differences vary between $5.5 \%$ (layer \#6) and $23.4 \%$ (layer \#3). The partial ozone column at layer \#3 (between $9.7 \mathrm{~km}$ and $14.7 \mathrm{~km}$, lower stratosphere) shows large differences (about $30 \mathrm{DU}$ ) when scenarios for extreme total ozone cases are compared. For this layer the a priori satellite climatology clearly underestimates the ozonesonde measured for higher total ozone values. This fact is also observed, although to a lesser degree, in layer \#2 (between $5.1 \mathrm{~km}$ and $9.7 \mathrm{~km}$, higher troposphere). This behaviour could partially explain the underestimation of higher ground-based total ozone measurements by GOME-2/MetOp, as seen in Fig. 5. In addition, the lowest two layers show relative differences higher than $15 \%$ between the measurements and the climatology. This may be attributed to high ozone variability on a synoptic scale (Vaughan and Price, 1991). However, the lowest layers have small partial ozone content, and overall the correspondingly high relative difference between ozonesonde and a priori profiles have minor influence on the satellite-retrieved total ozone result.

For the 48 days with ozonesonde observations, the relative differences between Brewer and GOME-2/MetOp ozone measurements have been compared with the relative differences between the ozonesonde profiles and the climatology profiles for each layer. The results (not shown) indicate that these differences are poorly correlated (coefficients of correlation lower than 0.1). Therefore, the climatology ozone profiles that are used in GDP 4.x have a minor error contribution to total ozone retrieval at Madrid. Similar results were obtained at Hohenpeissenberg (Germany) by Lamsal et al. (2007). This work also showed that the ozone profile sensitivity of total ozone retrieval is significantly larger in polar regions, in particular at high SZA.

\section{Conclusions}

The comparison between GOME-2/MetOp and Brewer total ozone data for one whole year of measurements in five locations in Spain shows an excellent agreement. The satellite total ozone underestimates the ground-based measurements with a mean offset of $3.05 \%$. Although the relative differences between GOME/ERS-2 data and Brewer measurements show a smaller offset, these differences have a significantly higher variability than the differences obtained when GOME-2/MetOp and Brewer total ozone data are compared. In addition, the total ozone data from the new GOME2/MetOp instrument shows no dependence on the solar elevation and cloudiness conditions. However, this instrument shows a slight dependence with respect to the total ozone values measured by Brewer spectroradiometers, and a significant dependence on the satellite scan angle. The direct comparison between both satellite instruments indicates that GOME-2/MetOp ozone data underestimates GOME/ERS-2 data by $1.46 \%$ on average, and the relative differences show no seasonal dependence.

The a priori ozone profiles used in the GOME-2/MetOp total ozone retrieval algorithm are compared with true ozone profiles from ozonesonde measurements. The results show that there is an excellent agreement in the middle and high stratosphere where the most part of the ozone amount is located, while the differences increase in the lower stratosphere and troposphere.

In summary, GOME-2/MetOp total ozone data already present an excellent quality, and it is suitable for assimilation in numerical weather prediction models, for long-term ozone monitoring, and for analysis of ozone trends and the expected ozone recovery.

Acknowledgements. The Brewer ozone data used in this study were provided by the Agencia Estatal de Meteorología (AEMet) (Madrid, Murcia, Zaragoza and A Coruña) and the Instituto Nacional de Técnica Aeroespacial (INTA) (El Arenosillo). The authors would like to thank to the German Aerospace Center (DLR) for providing the GOME/ERS-2 ozone data on behalf of ESA and GOME2/MetOp ozone data on behalf of EUMESAT O3M-SAF. This work was partially supported by Ministerio de Educación y Ciencia under project CGL2005-05693-C03-03/CLI and by Ministerio de Ciencia 
e Innovación under project CGL2008-05939-C03-02/CLI.

Topical Editor C. Jacobi thanks two anonymous referees for their help in evaluating this paper.

\section{References}

Antón, M., Loyola, D., Navascúes, B., and Valks, P.: Comparison of GOME total ozone data with ground data from the Spanish Brewer spectroradiometers, Ann. Geophys., 26, 401-412, 2008, http://www.ann-geophys.net/26/401/2008/.

Balis, D., Lambert, J. C., Van Roozendael, M., Spurr, R., Loyola, D., Livschitz, Y., Valks, P., Amiridis, V., Gerard, P., Granville, J., and Zehner, C.: Ten years of GOME/ERS2 total ozone data: the new GOME Data Processor (GDP) Version 4: II. Groundbased validation and comparisons with TOMS V7/V8, J. Geophys. Res., 112, D07307, doi:10.1029/2005JD006376, 2007a.

Balis, D., Koukouli, M., Loyola, D., Valks, P., and Hao, N.: Validation of GOME-2 total ozone products (OTO/O3, NTO/O3) processed with GDP 4.2, Report of the Satellite Application Facility on Ozone and Atmospheric Chemistry Monitoring (O3M-SAF), SAF/O3M/AUTH/GOME-2VAL/RP/01, $2007 \mathrm{~b}$.

Balis, D., Koukouli, M., Loyola, D., Valks, P., and Hao, N.: Second validation report of GOME-2 total ozone products (OTO/O3, NTO/O3) processed with GDP4.2, Report of the Satellite Application Facility on Ozone and Atmospheric Chemistry Monitoring (O3M-SAF), SAF/O3M/AUTH/GOME-2VAL/RP/02, 2008.

Bovensmann, H., Burrows, J. P., Buchwitz, M., Frerick, J., Noel S., Rozanov, V. V., Chance, K. V., and Goede, A. P. H.: SCIAMACHY: Mission objectives and measurement modes, J. Atmos. Sci., 56, 127-150, 1999.

Bramstedt, K., Gleason, J., Loyola, D., Thomas, W., Bracher, A., Weber, M., and Burrows, J. P.: Comparison of total ozone from the satellite instruments GOME and TOMS with measurements from the Dobson network 1996-2000, Atmos. Chem. Phys., 3, 1409-1419, 2003, http://www.atmos-chem-phys.net/3/1409/2003/.

Burrows, J. P., Weber, M., Buchwitz, M., Razonov, V., Ladstatter, A., Richter, A., De Beerk, R., Hoogen, R., Bramsdted, D., Eichmann, K. U., Eisenger, M., and Perner, D.: The Global Ozone Monitoring Experiment (GOME): mission concept and first scientific results, J. Atmos. Sci., 56, 151-175, 1999a.

Burrows, J., Richter, A., Dehn, A., Deters, B., Himmelmann, S., Voigt, S., and Orphal, J.: Atmospheric remote sensing reference data from GOME: Part 2. Temperature-dependent absorption cross-sections of $\mathrm{O}_{3}$ in the 231-794 nm range, J. Quant. Spectrosc. Radiat. Transfer, 61, 509-517, 1999 b.

Fioletov, V. E., Kerr, J. B., McElroy, C. T., Wardle, D. I., Savastiouk, V., and Grajnar, T. S.: The Brewer reference triad, Geophys. Res. Lett., 32, L20805, doi:10.1029/2005GL024244, 2005.

Fioletov, V. E., Labow, G., Evans, R., et al.: Performance of the ground-based total ozone network assessed using satellite data, J. Geophys. Res., 113, D14313, doi:10.1029/2008JD009809, 2008.

Hansen, G., Dahlback, A., Tønnessen, F., and Svenøe, T.: Validation of GOME total ozone by means of the Norwegian ozone monitoring network, Ann. Geophys., 17, 430-436, 1999, http://www.ann-geophys.net/17/430/1999/.

Kerr, J. B., McElroy, C., and Evans, V.: The automated Brewer spectrophotometer, In Proc. Quadrenial Ozone Symposium, Haldidiki, Greece, pp. 396-401, 1984.
Kerr, J. B.: New methodology for deriving total ozone and other atmospheric variables from Brewer spectrophotometer direct sun spectra, J. Geopshys. Res., 107(D23), 4731, doi:10.1029/2001JD001227, 2002.

Komhyr, W. D.: Electrochemical cells for gas analysis, Ann. Geophys., 25, 203-210, 1969.

Labajo, A., Cuevas, E., and de la Morena, B.: The first Iberian UV-visible instrument intercomparison. Final report, edited by: Instituto Nacional de Meterorologia (INM, Spain), 2004.

Lambert, J. C., Peeters, P., Richter, A., et al.: ERS-2 GOME data products delta characterization report, Issue 0.1, edited by: Lambert, J. C. and Skarlas, P., November 1999.

Lambert, J. C., Hansen, G., Soebijanta, V., Thomas, W., Van Roozendal, M., Balis, D., Fayt, C., Gerard, P., Gleason, J., Granville, J., Labow, G., Loyola, D., van Geffen, J., van Oss, R., Zehner, C., and Zerefos, C.: ERS-2 GOME GDP3.0 Implementation and Delta Validation Report for GOME Level-1 to Level 2 Data Processor Upgrade to Version 3.0, ESA Technical Note ERSE-DTEX-EOAD-TN-02-0006, 2002.

Lamsal, L. N., Weber, M., Labow, G., and Burrows, J. P.: Influence of ozone and temperature climatology on the accuracy of satellite total ozone retrieval, J. Geophys. Res., 112, D02302, doi:10.1029/2005JD006865, 2007.

Loyola D., Balzer, W., Aberle, B., Bittner, M., Kretschel, K., Mikusch, E., Muehle, H., Ruppert, T., Schmid, C., Slijkhuis, S., Spurr, R., Thomas, W., Wieland, T., and Wolfmueller, M..: Ground segment for ERS-2/GOME sensor at the German D-PAF, 3rd ERS Scientific Symposium, Florence, Italy, pp. 591-596, 1997.

Loyola, D., Thomas, W., Livschitz, Y., Ruppert, T., Albert, P., and Hollmann, R.: Cloud properties derived from GOME/ERS2 backscatter data for trace gas retrieval, IEEE Trans. Geosci. Remote Sens., 45, 2747-2758, 2007.

McPeters, R. D., Kroon, M., Labow, G., Brinksma, E., Balis, D., Petropavlovskikh, I., Veefkind, J. P., Bhartia, P. K., and Levelt, P. F.: Validation of the Aura Ozone Monitoring Instrument total column ozone product, J. Geophys. Res, 113, D15S14, doi:10.1029/2007JD008802, 2008.

Munro, R., Eisenger, M., Anderson, C., Callies, J., Carpaccioli, E., Lang, R., Lefevre, A., Livschitz, Y., and Albinana, A. P.: GOME2 on MetOp, In Proc. The 2006 EUMETSAT Meteorological Satellite Conference, Helsinki, Finland, EUMETSAT P.48, ISBN 92-9110-076-5, 2006.

Redondas, A., Cuevas, E., and Labajo, A.: Management and QA/QC of the Spanish Brewer spectrophotometer Network, in: Proc. Sixth European Symposium on Stratospheric Ozone, Göteborg, Sweden, 2002.

Spurr, R., Loyola, D., Thomas, W., et al.: GOME level 1-to-2 data processor version 3.0: a major upgrade of the GOME/ERS-2 total ozone retrieval algorithm, Appl. Optics, 44, 7196-7209, 2005.

Valks, P. and Loyola, D.: Algorithm Theoretical Basis Document for GOME-2 Total Column Products of Ozone, Minor Trace Gases, and Cloud Properties (GDP 4.2 for O3M-SAF OTO and NTO), Report of the Remote Sensing Institute- German Aerospace Center (IMF-DLR), DLR/GOME-2/ATBD/01, 2008. van Roozendael, M., Loyola, D., Spurr, R., Balis, D., Lambert, J. C., Livschitz, Y., Valks, P., Ruppert, T., Kenter, P., Fayt, C., and Zehner, C.: Ten years of GOME/ERS2 total ozone data: the new GOME Data Processor (GDP) Version 4:I.Algoritm Description, 
J. Geophys. Res., 111, D14311, doi:10.1029/2005JD006375, 2006.

Vanicek, K.: Differences between ground Dobson, Brewer and satellite TOMS-8, GOME-WFDOAS total ozone observations at Hradec Kralove, Czech, Atmos. Chem. Phys., 6, 5163-5171, 2006, http://www.atmos-chem-phys.net/6/5163/2006/.

Vaughan, G. and Price, J.: On the relation between total ozone and meteorology, Q. J. Roy. Meteor. Soc., 117, 1281-1298, 1991.
WMO, World Meteorological Organization: Guide to meteorological instruments and methods of observation, 6th ed. WMO Publication \#8, Geneva, 1996.

WMO, World Meteorological Organization: WMO/CEOS report on a strategy for integrating satellite and ground-based observations of ozone. GAW Technical Report no. 140, 1999.

WMO, World Meteorological Organization: Scientific assessment of ozone depletion: Global ozone research and monitoring project, Technical Report 50, 2006. 